\title{
BÜYÜK ve ORTA BOY İŞLETMELER için FINANSAL RAPORLAMA STANDARDI (BOBİ FRS) ile TAM SET TÜRKİYE MUHASEBE ve TÜRKIYYE FINANSAL RAPORLAMA STANDARTLARININ (TMS/TFRS) KARŞILAŞTIRILMASI \\ COMPARISON of FINANCIAL REPORTING STANDARD for LARGE and MEDIUM SIZED ENTERPRISES (FRS for LMEs) with the FULL SET TURKISH ACCOUNTING and TURKISH FINANCIAL REPORTING STANDARDS (TAS/TFRS)
}

Özet

\author{
Başak ATAMAN ${ }^{*}$ Hakan CAVLAK ${ }^{* *}$
}

Türkiye'de bağımsız denetime tabi olup Tam Set TMS/TFRS uygulamak zorunda olmayan işletmeler için geçerli finansal raporlama çerçevesi BOBİ FRS adı ile 29 Temmuz 2017 tarihinde yayımlanmıştır. Bu standart, 1 Ocak 2018'den itibaren bağımsız denetime tabi olup Tam Set TMS/TFRS kapsamı dışında kalan büyük ve orta ölçekli işletmelerin hazırlayacakları münferit ve konsolide finansal tablolar için bir rehber niteliğindedir. Çalışmada, öncelikle BOBİ FRS'nin genel özellikleri verilmiş olup daha sonra ise bu standardın Tam Set TMS/TFRS ile karşılaştırması yapılmıştır. Her iki düzenleme arasındaki benzer ve farklılıklar BOBİ FRS'deki bölümler kapsamında ele alınmış ve ortaya çıkan konularda genel bir değerlendirmede bulunulmuştur. Düzenlemeler, işletmelerin uygulayacakları temel ilkeler çerçevesinde karşılaştırıldığında düzenlemelerin büyük ölçüde uyumlu olduğu, bununla birlikte bazı temel farklılıkların da bulunduğu tespit edilmiştir. Her iki düzenleme dışında BOBİ FRS'nin kendi içinde de büyük ve orta ölçekli işletmeler açısından farklı düzenlemelere sahip olduğu da görülmüştür.

Anahtar Kelimeler: Finansal Raporlama Standartları, BOBİ FRS, TMS, TFRS.

JEL Sinıflamasi: M41, M48, M49.

\begin{abstract}
In Turkey, the financial reporting framework to be applied by enterprises subject to independent audit and not obliged to implement full Set TAS/TFRS was issued on July 29, 2017 under the name of FRS for LMEs. This standard will be effective as of January 1, 2018 and is a guide for separate and consolidated financial statements to be prepared by large and medium-sized enterprises out of scope the TAS/TFRS. In the study, firstly, the general characteristics of FRS for LMEs were given and then this standard was compared with TAS/TFRS. The similarities and differences between the two regulations have been considered within the context of the sections in the FRS for LMEs and the results were evaluated. As a result of the evaluation of the regulations, it seems that there is a great deal of harmony between the two arrangements. It has also been found that there are some fundamental differences. Apart from both arrangements, it is also seen that FRS for LMEs has different regulations in terms of large and medium sized enterprises in itself.
\end{abstract}

Keywords: Financial Reporting Standards, FRS for LMEs, TAS, TFRS.

JEL Classification: M41, M48, M49.

\footnotetext{
* Prof. Dr., Marmara Üniversitesi İşletme Fakültesi İşletme Bölümü, bataman@marmara.edu.tr

** Arş. Gör., Marmara Üniversitesi İşletme Fakültesi İşletme Bölümü, hakan.cavlak@marmara.edu.tr
} 


\section{GíRiş}

1990‘lardan başlayarak günümüze kadar süregelen dönem olarak tanımlanan bilgi çağında işletmeler, bilgi teknolojilerine dayalı faaliyet göstermekte ve pek çok ürün ve hizmet de bu teknoloji ile iç içe bulunmaktadır. Bu sürecin olumsuz etkileri olarak da; nükleer silahlanma, küresel ısınma, insan gücünden otomasyona geçiş sonucu artan işsizlik ve benzeri problemleri karşımıza çıkmaktadır. Son otuz yıldaki bu ve benzeri gelişmeler, işletmelerin de sınırını ortadan kaldırmış, bu da globalleşen işletmelerin ortak bir dil konuşmasını bir başka ifade ile ortak bir raporlama dili kullanmasını bir zorunluluk haline getirmiştir.

Finansal raporlama açısından işletmelerin kullandıkları ortak dil olarak bugün dünyada finansal raporlamaya yön veren standart seti olan ve Uluslararası Muhasebe Standartlarl Kurulu tarafindan oluşturulan Uluslararası Finansal Raporlama Standartları (UFRS) olarak görülmektedir. UFRS’ler, dünyada uygulanma ve işletmeler tarafından benimsenme düzeyine bakıldığında finansal raporlama konusunda otorite olma yolunda emin adımlarla ilerlemektedir.

Bugün, 150 ülkede kullanılan veya uyumlaştırma çalışmaları yapılan UFRS setinin ülke genelinde kullanımları incelendiğinde, bunların halka açık işletmeler nezdinde yoğunluklu olarak kullanıldığı görülmektedir. Ülkedeki diğer işletmeler ise ülkenin ulusal standartlarını kullanmakta ya da ülkede UFRS ile uyumlu ulusal standart oluşturma çalışmaları yapılmaktadır. UFRS'lerin tüm işletmeler tarafından uygulanamamasının ya da ulusal standart oluşturma çalışmalarının nedeni ise UFRS'lerin kullanımı ile ortaya çıkacak vergisel farklılıklar ve sette yoğunluklu olarak benimsenen gerçeğe uygun değer ve kullanımının yaratacağı sübjektif durumlar olarak görülmektedir.

Finansal raporlamada Türkiye’deki duruma bakıldığında, Türk Ticaret Kanunun 2012 yılındaki yenilenmesine kadar Türkiye Finansal Raporlama Standartlarının (TFRS -UFRS'lerin birebir Türkçe çevirileri-) kullanımı, SPK'ya tabi halka açık işletmelerle sınırlı tutulmuştur. Türk Ticaret Kanunun yenilenmesi aşamasında, halka açık olmayan diğer işletmelere de standartlara uygun bağımsız denetim raporu hazırlama ve defter kayıtlarını standartlara göre oluşturma zorunluluğu getirilmesi büyük yankı uyandırmıştır. Sonraki süreçte ise kayıtların standartlara göre yapılması zorunluluğu kanun yürürlüğe girmeden kaldırılmış, ardından da bağımsız denetime tabi olacak işletme kriterlerinin Bakanlar kurulu kararı ile düzenlenmesi getirilmiştir. Bu düzenlemelerin ardından 2014 yılında Kamu Gözetimi Kurumu $(K G K)$, TFRS uygulama kapsamını bağımsız denetim kapsamından ayrıştırarak, diğer ülke uygulamalarında olduğu gibi Kamu Yararını İlgilendiren Kuruluşlar (KAYİK) ile sınırlandırmıştır.

Bu gelişmelerden sonra, bağımsız denetime tabi ancak TFRS uygulamayan işletmelerin, ilk olarak Maliye Bakanlığı tarafından yayınlanmış olan Muhasebe Sistemi Uygulama Genel Tebliği (MSUGT) hükümlerini uygulamaları ardında da MSUGT'ye ek olarak 2014 tarihinde KGK tarafindan yayımlanan Bağımsız Denetime Tabi Olup TMS'leri Uygulamayan Şirketlerin Finansal Tablolarının Hazırlanmasında ve Sunulmasında Uygulanacak Ilave Hususlararı uygulamaları zorunlu tutulmuştur. İlave hususlar, KGK tarafından yeni bir standart seti hazırlanıncaya kadar geçici bir çözüm olarak tasarlanmıştır (Gökçen,Ataman,Çakıcı, 2016:22).

Bağımsız denetime tabi olup Tam Set TMS/TFRS uygulamayan işletmeler için uygulanacak finansal raporlama standardı konusunda KGK, 2014 yılında çalışmalara başlamış ve çalışma nihai hale gelinceye kadar Yerel Finansal Raporlama Çerçevesi (YFRÇ) olarak isimlendirilmiştir. Gerçeğe ve ihtiyaca uygun, karşılaştırılabilir finansal bilgi sunumunu sağlayacak yerel bir finansal raporlama standardının çıkarılması çalışmaları, 2017 tarihinde sonuçlanmış olup standart, 29 Temmuz 2017 tarihli ve 30138 sayılı Mükerrer Resmi Gazetede Büyük ve Orta Boy Isşletmeler İçin Finansal Raporlama Standardı (BOBİ FRS) adı ile yayınlanmıştır.

Bu çalışmada, yukarıda anlatılan süreç nihayetinde yürürlüğe giren BOBİ FRS detaylı bir şekilde ele alınmakta ve Tam Set TMS/TFRS ile karşılaştırması yapılmaktadır. Çalışmanın amacı, 1 Ocak 2018 tarihi itibari ile uygulanacak olan BOBİ FRS hakkında genel bir çerçeve oluşturmak ve BOBİ FRS ile Tam Set TMS/TFRS düzenlemeleri arasındaki farklılıkların neler olduğunu ortaya koymaktır. Bununla birlikte son olarak, yapılan inceleme kapsamında ortaya çıkan tablo hakkında değerlendirmelerde bulunulmuştur.

\section{BÜYÜK VE ORTA BOY İŞLETMELER İÇIN FİNANSAL RAPORLAMA STANDARDI}

Büyük ve Orta Boy İşletmeler için Finansal Raporlama Standardı (BOBİ FRS), bağımsız denetime tabi olup Türkiye Muhasebe/Finansal Raporlama Standartlarını (TMS/TFRS’yi) uygulamayan işletmelerin genel kurullarına sundukları finansal tablolar açısından geçerli finansal raporlama çerçevesidir (KGK, 2017:1). 
Standarda dair genel bilgiler, Tablo 1’de görüldüğü gibidir.

Tablo 1. BOBİ FRS Hakkında Genel Bilgiler

\begin{tabular}{|l|l|}
\hline \multicolumn{2}{|c|}{ (Büyük ve Orta Boy İşletmeler için Finansal Raporlama Standardı) } \\
\hline Düzenleyici & KGK (Kamu Gözetimi Muhasebe ve Denetim Standartları Kurumu) \\
\hline Yayımlanma Tarihi ve Yeri & $\begin{array}{l}\text { 29.07.2017 tarihli Resmi Gazete (Sayı: 30138 Mükerrer) } \\
\text { BOBİ FRS Hakkında Tebliğ (Sıra No: 56) }\end{array}$ \\
\hline Uygulanma Tarihi & 01.01.2018 tarihi ve sonrasında başlayan hesap dönemleri \\
\hline Uygulayacak Olan İşletmeler & Bağımsız denetime tabi olup TFRS'yi uygulamayan işletmeler \\
\hline Kapsamı & Münferit ve Konsolide Finansal Tablolar \\
\hline İçerik & 27 Bölüm ve 9 Ek (bkz. Tablo 2) \\
\hline
\end{tabular}

27 Bölüm ve Finansal Tablolar ile Tanımları içeren 9 Ek’ten oluşan BOBİ FRS’nin detaylı içeriği, Tablo 2'de verilmektedir.

Tablo 2. BOBİ FRS İçeriği

\begin{tabular}{|c|c|c|c|}
\hline \multirow{9}{*}{ 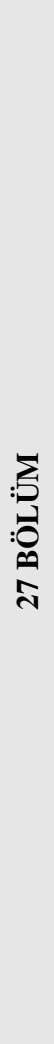 } & $\begin{array}{l}\text { B1 Kavramsal Çerçeve ve Finansal } \\
\text { Tablolar }\end{array}$ & B2 Nakit Akış Tablosu & $\begin{array}{l}\text { B3 Muhasebe Politikaları, } \\
\text { Tahminler ve Yanlışlıklar }\end{array}$ \\
\hline & $\begin{array}{l}\text { B4 Raporlama Döneminden Sonraki } \\
\text { Olaylar }\end{array}$ & B5 Hasilat & B6 Stoklar \\
\hline & B7 Tarımsal Faaliyetler & $\begin{array}{l}\text { B8 Maden Kaynaklarının } \\
\text { Aranması ve } \\
\text { Değerlendirilmesi }\end{array}$ & $\begin{array}{l}\text { B9 Finansal Araçlar ve } \\
\text { Özkaynaklar }\end{array}$ \\
\hline & B10 İştiraklerdeki Yatırımlar & $\begin{array}{l}\text { B11 Müşterek Girişimlerdeki } \\
\text { Yatırımlar }\end{array}$ & B12 Maddi Duran Varlıklar \\
\hline & B13 Yatırım Amaçlı Gayrimenkuller & $\begin{array}{l}\text { B14 Maddi Olmayan Duran } \\
\text { Varlıklar }\end{array}$ & B15 Kiralamalar \\
\hline & B16 Devlet Teşvikleri & B17 Borçlanma Maliyetleri & $\begin{array}{l}\text { B18 Varlıklarda Değer } \\
\text { Düşüklüğü }\end{array}$ \\
\hline & $\begin{array}{l}\text { B19 Karş1lıklar, Şarta Bağlı } \\
\text { Yükümlülükler ve Şarta Bağlı } \\
\text { Varlıklar }\end{array}$ & $\begin{array}{l}\text { B20 Yabancı Para Çevrim } \\
\text { İşlemleri }\end{array}$ & B21 İş Birleşmeleri \\
\hline & B22 Konsolide Finansal Tablolar & $\begin{array}{l}\text { B23 Gelir Üzerinden Alınan } \\
\text { Vergiler }\end{array}$ & $\begin{array}{l}\text { B24 Ara Dönem Finansal } \\
\text { Raporlama }\end{array}$ \\
\hline & $\begin{array}{l}\text { B25 Yüksek Enflasyonlu } \\
\text { Ekonomilerde Finansal Raporlama }\end{array}$ & B26 Dipnotlar & B27 Geçiş Hükümleri \\
\hline \multirow{3}{*}{$\begin{array}{l}\frac{x}{151} \\
\sigma\end{array}$} & E1 Finansal Durum Tablosu & E2 Kâr veya Zarar Tablosu & E3 Özkaynak Değişim Tablosu \\
\hline & E4 Nakit Akış Tablosu & $\begin{array}{l}\text { E5 Konsolide Finansal Durum } \\
\text { Tablosu }\end{array}$ & $\begin{array}{l}\text { E6 Konsolide Kâr veya Zarar } \\
\text { Tablosu }\end{array}$ \\
\hline & $\begin{array}{l}\text { E7 Konsolide Özkaynak Değişim } \\
\text { Tablosu }\end{array}$ & $\begin{array}{l}\text { E8 Konsolide Nakit Akış } \\
\text { Tablosu }\end{array}$ & E9 Tanımlar \\
\hline
\end{tabular}


BOBİ FRS'nin amaçları ise şu şekilde tanımlanmaktadır (KGK, 2017:1):

$\checkmark$ Gerçeğe uygun,

$\checkmark$ Finansal bilgi ihtiyacina uygun ve

$\checkmark$ Karşılaştırılabilir finansal tablolar düzenlenmesini sağlamaktır.

Bu amaçlar çerçevesinde KGK tarafından hazırlanan BOBİ FRS, Tam Set TMS/TFRS'ye göre daha sade bir dille hazırlanmış olup büyük ve orta ölçekli işletmeler için gerekli olmayan detaylardan kaçınılarak sadece ilgili konularda temel ilkelere değinilmiştir.

BOBİ FRS'nin diğer genel özellikleri ise şu şekilde belirtilmektedir (KGK, 2017:2):

$\checkmark$ İşletmelerin genel olarak karşılaşabileceği tüm muhasebe işlemlerine ilişkin muhasebe esaslarını belirlemektedir. Bu yönüyle başka bir standart setine ihtiyaç duyulmadan finansal tabloların hazırlanmasına imkân vermekte ve kabul edilebilir bir finansal raporlama çerçevesinin gerektirdiği tüm özellikleri taşımaktadır.

Uluslararası muhasebe ve finansal raporlama uygulamalarıyla ve AB düzenlemeleriyle uyumludur. AB Muhasebe Direktifindeki “önce küçükleri düşün” yaklaşımına da uygun olarak, orta büyüklükteki işletmeler için genel olarak maliyet esaslı bir finansal raporlama öngörülmüş; büyük işletmelere yönelik ise ilâve yükümlülükler getirilmiştir.

$\checkmark$ Bölümler sade ve anlaşılabilir bir dille kaleme alınmıştır.

\section{BOBİ FRS VE TAM SET TMS/TFRS KARŞILAŞTIRMASI}

Bu bölümde, öncelikle BOBİ FRS ve Tam Set TMS/TFRS, bu standartları uygulayacak olan işletmelerin büyüklükleri itibari ile karşılaştırılmıştır. Daha sonra ise BOBİ FRS'de yer alan tüm bölümler, Tam Set TMS/TFRS'de bu bölümleri ilgilendiren standart ile karşılaştırılmış olup benzer ve farklı düzenlemelerin neler olduğu ortaya konmuştur.

\subsection{BOBİ FRS \& Tam Set TMS/TFRS: Uygulayacak Olan İşletmeler}

BOBİ FRS ve Tam Set TMS/TFRS'lerin kapsamına giren işletmelerin hangi işletmeler olduğu Tablo 3 ve Şekil 1'de gösterilmektedir.

Tablo 3. BOBİ FRS Kapsamı

\begin{tabular}{|c|c|c|c|c|c|}
\hline & & \multicolumn{4}{|c|}{ UYGULAMA } \\
\hline & & Bağımsız Denetim & TFRS & ВOBİ FRS & MSUGT \\
\hline \multirow{4}{*}{ 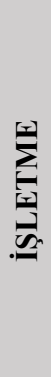 } & KAYİK & $\checkmark$ & $\checkmark$ & - & - \\
\hline & Büyük Ölçekli & $\checkmark$ & $*$ & $\checkmark$ & - \\
\hline & Orta Ölçekli & $\checkmark$ & $*$ & $\checkmark$ & - \\
\hline & Küçük Ölçekli & - & - & - & $\checkmark$ \\
\hline
\end{tabular}

* Büyük ve Orta Ölçekli İşletmeler, TFRS'yi ihtiyari olarak uygulayabilirler. 
Şekil 1. BOBİ FRS \& Tam Set TMS/TFRS Kapsamı

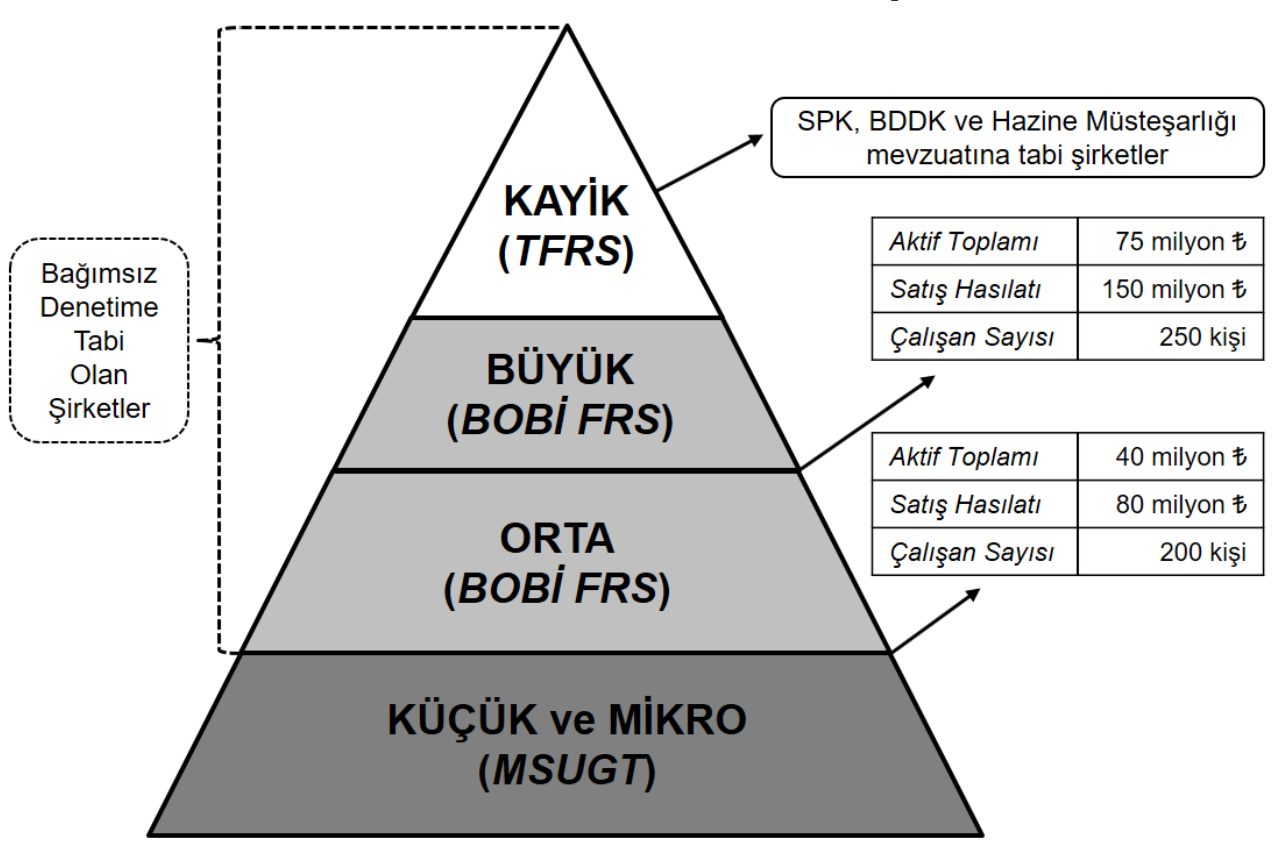

Kaynak: KGK, BOBİ FRS Tanıtım Toplantısl, İstanbul (14.09.2017).

Şekil ve tablodan da görüleceği gibi Tam Set TMS/TFRS'ler, Kamu Yararını İlgilendiren Kuruluşlar (KAYIK'ler) tarafindan; BOBİ FRS'ler ise bağımsız denetime tabi olup TMS/TFRS uygulamak zorunda olmayan işletmeler tarafindan uygulanacaktır.

Genel hatları ile BOBİ FRS'ler değerlendirildiğinde setin en önemli noktasının Büyük ve Orta Ölçekli İşletmeleri birbirinden belirlenen kriterlerle (Aktif Toplamı, Satı̧̧ Hasılatı ve Çalışan Sayısı) ayırması olduğu görülmektedir. Bağımsız denetime tabi olma kriterlerini sağlayan işletmeler, tebliğde belirtilen büyük ölçekli işletme eşiğgine gelene kadar Orta Boy İşletmeler olarak; bu eşiği ve üstünü sağlayan (KAYİK dışındaki) işletmeler ise Büyük Boy İşletmeler olarak tanımlanmaktadır.

Şekil 1'de görülen ve bağımsız denetime tabi olma ve büyük işletme eşiklerinde belirtilen üç kriterden en az ikisini art arda iki raporlama döneminde aşan işletmeler, müteakip raporlama döneminde bağımsız denetime tabi olmakta ya da büyük ölçekli işletme sayılmaktadır. Bağımsız denetim kriterlerini sağlayıp büyük işletme kriterlerini sağlayamayan işletmeler ise orta ölçekli işletme sayılmaktadır.

KGK verilerine göre, 2016 yllında bağımsız denetim sözleşmesi imzalayan 6.250 şirketten; 1.550 'si TFRS, 4.700'si BOBI FRS (850'si Büyük Ölçekli İşletme, 3.850'si Küçük Ölçekli İşletme) kapsamına girmektedir. Bu veriler, BOBİ FRS'nin uygulama alanının 1 Ocak 2018'den itibaren ne kadar geniş olacağını göstermesi açısından önem arz etmektedir.

\subsection{BOBİ FRS \& Tam Set TMS/TFRS: Bölüm \& Standart Karşılaştırması}

Tablo 4'te BOBİ FRS'de yer alan bölümlerin Tam Sette yer alan hangi standart ile ilgili olduğu ve bu çalışma kapsamında yapılan karşılaştırmada hangi bölüm ile hangi standardın ele alındığı; Tablo 5 'te ise BOBİ FRS'de yer almayan Tam Set TMS/TFRS düzenlemelerinin hangileri olduğu yer almaktadır.

Tablo 4. BOBİ FRS Bölümlerinin Tam Set TMS/TFRS'de Karșılı̆̆ 1 Olan Standartlar

\begin{tabular}{|l|c|l|c|}
\hline BOBİ FRS & $\begin{array}{l}\text { Sayfa } \\
\text { Sayısı }\end{array}$ & Tam Set TMS/TFRS & $\begin{array}{c}\text { Sayfa } \\
\text { Sayısı }\end{array}$ \\
\hline $\begin{array}{l}\text { B1 Kavramsal Çerçeve ve Finansal } \\
\text { Tablolar }\end{array}$ & 11 & $\begin{array}{l}\text { Finansal Raporlamaya İlişkin Kavramsal Çerçeve } \\
\text { ile TMS 1 Finansal Tabloların Sunuluşu }\end{array}$ & 48 \\
\hline B2 Nakit Akış Tablosu & 5 & TMS 7 Nakit Akış Tabloları & 13 \\
\hline $\begin{array}{l}\text { B3 Muhasebe Politikaları, Tahminler ve } \\
\text { Yanlışlıklar }\end{array}$ & 9 & $\begin{array}{l}\text { TMS 8 Muhasebe Politikaları, Muhasebe } \\
\text { Tahminlerinde Değişiklikler ve Hatalar }\end{array}$ & 10 \\
\hline $\begin{array}{l}\text { B4 Raporlama Döneminden Sonraki } \\
\text { Olayla }\end{array}$ & 3 & $\begin{array}{l}\text { TMS 10 Raporlama Döneminden (Bilanço } \\
\text { Tarihinden) Sonraki Olaylar }\end{array}$ & 6 \\
\hline
\end{tabular}




\begin{tabular}{|c|c|c|c|}
\hline B5 Hasilat & 9 & TMS 11 İnşaat Sözleşmeleri ve TMS 18 Hasılat & 16 \\
\hline B6 Stoklar & 6 & TMS 2 Stoklar & 8 \\
\hline B7 Tarımsal Faaliyetler & 4 & TMS 41 Tarımsal Faaliyetler & 9 \\
\hline $\begin{array}{l}\text { B8 Maden Kaynaklarının Aranması ve } \\
\text { Değerlendirilmesi }\end{array}$ & 3 & $\begin{array}{l}\text { TFRS } 6 \text { Maden Kaynaklarının Araştırılması ve } \\
\text { Değerlendirilmesi }\end{array}$ & 6 \\
\hline B9 Finansal Araçlar ve Özkaynaklar & 20 & $\begin{array}{l}\text { TMS } 32 \text { Finansal Araçlar: Sunum } \\
\text { TMS } 39 \text { Finansal Araçlar: Muhasebeleştirme ve } \\
\text { Ölçme } \\
\text { TFRS } 7 \text { Finansal Araçlar: Açılamalar } \\
\text { TFRS } 9 \text { Finansal Araçlar }\end{array}$ & 275 \\
\hline B10 İştiraklerdeki Yatırımlar & 8 & $\begin{array}{l}\text { TMS } 28 \text { İştiraklerdeki ve İş Ortaklıklarındaki } \\
\text { Yatırımlar }\end{array}$ & 9 \\
\hline B11 Müşterek Girişimlerdeki Yatırımlar & 4 & TFRS 11 Müşterek Anlaşmalar & 19 \\
\hline B12 Maddi Duran Varlıklar & 6 & TMS 16 Maddi Duran Varlıklar & 14 \\
\hline B13 Yatırım Amaçlı Gayrimenkuller & 4 & TMS 40 Yatırım Amaçlı Gayrimenkuller & 15 \\
\hline B14 Maddi Olmayan Duran Varlıklar & 7 & TMS 38 Maddi Olmayan Duran Varlıklar & 23 \\
\hline B15 Kiralamalar & 7 & TMS 17 Kiralama İşlemleri & 12 \\
\hline B16 Devlet Teşvikleri & 2 & $\begin{array}{l}\text { TMS } 20 \text { Devlet Teşviklerinin } \\
\text { Muhasebeleştirilmesi ve Devlet Yardımlarının } \\
\text { Açıklaması }\end{array}$ & 6 \\
\hline B17 Borçlanma Maliyetleri & 1 & TMS 23 Borçlanma Maliyetleri & 5 \\
\hline B18 Varlıklarda Değer Düşüklüğü & 9 & TMS 36 Varlıklarda Değer Düşüklüğü & 33 \\
\hline $\begin{array}{l}\text { B19 Karş1lıklar, Şarta Bağlı } \\
\text { Yükümlülükler ve Şarta Bağlı Varlıklar }\end{array}$ & 6 & $\begin{array}{l}\text { TMS } 37 \text { Karş1lıklar, Koşullu Borçlar ve Koşullu } \\
\text { Varlıklar }\end{array}$ & 14 \\
\hline B20 Yabancı Para Çevrim İşlemleri & 9 & TMS 21 Kur Değişiminin Etkileri & 12 \\
\hline B21 İş Birleşmeleri & 7 & TFRS 3 İşletme Birleşmeleri & 33 \\
\hline B22 Konsolide Finansal Tablolar & 10 & TFRS 10 Konsolide Finansal Tablolar & 43 \\
\hline B23 Gelir Üzerinden Alınan Vergiler & 10 & TMS 12 Gelir Vergileri & 27 \\
\hline B24 Ara Dönem Finansal Raporlama & 7 & TMS 34 Ara Dönem Finansal Raporlama & 11 \\
\hline $\begin{array}{l}\text { B25 Yüksek Enflasyonlu Ekonomilerde } \\
\text { Finansal Raporlama }\end{array}$ & 6 & $\begin{array}{l}\text { TMS } 29 \text { Yüksek Enflasyonlu Ekonomilerde } \\
\text { Finansal Raporlama }\end{array}$ & 5 \\
\hline B26 Dipnotlar & 14 & $\begin{array}{l}\text { TMS } 1 \text { Finansal Tabloların Sunuluşu ve her } \\
\text { standardın kendi içinde dipnotlarda yapılması } \\
\text { gereken açılamaların neler olacağına yer } \\
\text { verilmektedir. }\end{array}$ & - \\
\hline B27 Geçiş Hükümleri & 8 & $\begin{array}{l}\text { TFRS } 1 \text { Türkiye Finansal Raporlama } \\
\text { Standartlarının İlk Uygulaması }\end{array}$ & 31 \\
\hline \multicolumn{2}{|l|}{ TOPLAM: 27 Bölüm / 195 sayfa } & \multicolumn{2}{|l|}{ TOPLAM: 30 standart ve Kavramsal Çerçeve / 703 sayfa } \\
\hline
\end{tabular}


Tablo 5. BOBİ FRS Bölümlerinin Tam Set TMS/TFRS’de Karşıllı̆̆ Olmayan Standartlar

\begin{tabular}{|c|c|}
\hline \multicolumn{2}{|c|}{ BOBİ FRS'de Yer Almayan Tam Set TMS/TFRS Düzenlemeleri } \\
\hline TFRS (8 standart) & TMS (5 standart) \\
\hline $\begin{array}{l}\text { TFRS } 2 \text { Hisse Bazlı Ödemeler, TFRS } 4 \text { Sigorta } \\
\text { Sözleşmeleri, TFRS } 5 \text { Satış Amaçlı Elde Tutulan Duran } \\
\text { Varlıklar ve Durdurulan Faaliyetler, TFRS } 8 \text { Faaliyet } \\
\text { Bölümleri, TFRS } 12 \text { Diğer İşletmelerdeki Paylara İlişkin } \\
\text { Açıklamalar, TFRS } 13 \text { Gerçeğe Uygun Değer Ölçümü, } \\
\text { TFRS } 14 \text { Düzenlemeye Dayalı Erteleme Hesapları, } \\
\text { TFRS } 15 \text { Müşteri Sözleşmelerinden Hasılat }\end{array}$ & $\begin{array}{l}\text { TMS } 19 \text { Çalışanlara Sağlanan Faydalar, TMS } 24 \\
\text { İlişkili Taraf Açılamaları, TMS } 26 \text { Emeklilik Fayda } \\
\text { Planlarında Muhasebeleştirme ve Raporlama, TMS } 27 \\
\text { Bireysel Finansal Tablolar, TMS } 33 \text { Hisse Başına } \\
\text { Kazanç }\end{array}$ \\
\hline UPLAIV: 13 standart / 260 sayra & \\
\hline
\end{tabular}

Tablo 4 ve Tablo 5 birlikte değerlendirildiğinde Tam Set TMS/TFRS içinde yer alan toplam 44 düzenlemeden (28 adet TMS, 15 adet TFRS ve Kavramsal Çerçeve -yorumlar dahil edilmemiştir-) 31 tanesi (703 sayfa), BOBİ FRS'de yer alan toplam 27 bölüm ile uyumlaştırılmış olup geriye kalan 13 düzenleme (260 sayfa, bkz. Tablo 5) ise BOBİ FRS'de yer almamıştır.

Tablo 4'te yer alan bilgiler kapsamında yapılan karşılaştırmaların önemli noktaları aşağıda BOBİ FRS bölüm başlıkları halinde sunulmaktadır.

\section{Bölüm 1 Kavramsal Çerçeve ve Finansal Tablolar}

TMS 1 Finansal Tabloların Sunuluşu ve Finansal Raporlamaya İlişkin Kavramsal Çerçevenin birleşiminden oluşmaktadır. BOBİ FRS'de yer alan ihtiyatlılık kavramı dışındaki ilkeler (Süreklilik, tahakkuk, netleştirme, tutarlılık, vb.), Tam Set TMS/TFRS ile uyumludur.

Bölüm 1'in Tam Set TMS/TFRS ile farklılaştı̆̆ı noktalar ise şunlardır:

$\checkmark$ Finansal Durum Tablosunda satış amaçlı duran varlıklar kalemi yer almamaktadır.

$\checkmark$ Kâr veya Zarar Tablosu basitleştirilmiş ve kapsamlı gelir sunumu kaldırılmıştır.

$\checkmark$ Kâr veya Zarar Tablosundaki, esas ve diğer faaliyet gelirleri (giderleri) gruplaması daha netleştirilmiştir. Durdurulan faaliyet ve sürdürülen faaliyet ayırımı kaldırılmıştır.

\section{Bölüm 2 Nakit Akış Tablosu}

TMS 7 Nakit Akış Tabloları standardındaki düzenlemeler (Faaliyetlerin sınıflandırılması, nakit akış hazırlama yöntemleri: doğrudan ve dolaylı yöntem, vb.) ile uyumludur. Sadece nakit akışlarının sınıflandırılmasında TMS 7'de işletme faaliyetleri olarak sunulan faaliyetler BOBİ FRS Bölüm 2'de esas faaliyetler olarak isimlendirilmiştir.

\section{Bölüm 3 Muhasebe Politikaları, Tahminler ve Yanlışlıklar}

TMS 8 Muhasebe Politikaları, Muhasebe Tahminlerinde Değişiklikler ve Hatalar standardında yer alan düzenlemeler (Politika değişikliği ve yanlışlıklar: geriye dönük uygulama; tahmin değişikliği: ileriye dönük uygulama, $v b$.) ile uyumludur.

\section{Bölüm 4 Raporlama Döneminden Sonraki Olaylar}

TMS 10 Raporlama Döneminden (Bilanço Tarihinden) Sonraki Olaylar standardındaki düzenlemeler (Raporlama döneminden sonraki düzeltme gerektiren ve gerektirmeyen olaylar, vb.) ile uyumludur.

\section{Bölüm 5 Hasılat}

TMS 18 Hasılat ve TMS 11 İnşaat Sözleşmeleri standartlarında yer alan düzenlemeler (Hasılatın kayda alınması, ölçümü, mal satışı, hizmet sunumu, inşa sözleşmeleri, vb.) ile uyumludur. BOBİ FRS Bölüm 5 'in muhasebe standartlarındaki düzenlemelerden ayrılan en önemli farklılığı, vade farklarının ayrıştırılması konusundadir.

TMS 18'de hasılat tutarından tüm vade farkları süreye bakılmaksızın ayrıştırılmakta iken, BOBİ FRS’de hasılat tutarının bir yıl veya daha kısa sürede tahsil edilmesinin öngörülmesi durumunda vade farkları ayrıştırılmamaktadır. Bir yıldan uzun vade farkları söz konusu ise vade farkı, etkin faiz yöntemine göre ayrıştırılmakta ve faiz geliri olarak muhasebeleştirilmektedir. 
1 Ocak 2018'den itibaren TMS 18 Hasılat standardının yerini alacak TFRS 15 Müşteri Sözleşmelerinden Hasılat standardı ve bu standartta yer alan beş aşamalı model, uygulamada büyük ve orta boy işletmeler açısından güçlük yaratabileceği için BOBİ FRS Bölüm 5, TFRS 15 yerine TMS 18 ile uyumlaştırılmıştır.

\section{Bölüm 6 Stoklar}

TMS 2 Stoklar standardında yer alan düzenlemeler (Ölçüm: maliyet ile net gerçekleşebilir değerden düşük olanı; stok de ğer düşüklüğ̈̈, vb.) ile çoğunlukla uyumludur. İki düzenleme arasındaki önemli farklılıklar ise şunlardir:

$\checkmark$ En önemli farklılık konusu, stok alımında vade farklarının ayrıştırılmasıdır. TMS 2’de tüm vade farkları ayrıştırılırken; BOBİ FRS Bölüm 6'da sadece bir yıldan uzun vadeli alımlarda vade fark1 ayrıştırılmakta ve faiz gideri olarak muhasebeleştirilmekte, bir yıldan kısa vadeli alımlarda ise vade farkı ayrıştırılmamaktadır.

$\checkmark$ BOBİ FRS'de stoklara ilişkin borçlanma maliyetleri, oluştukları dönemde kâr veya zarara yansıtılmaktadır. Sadece, üretilmesi normal şartlar altında bir yıldan daha uzun süren stoklar için katlanılan borçlanma maliyetleri satışa hazır hale geldiği tarihe kadar stokun maliyetine dahil edilmektedir. Bu durum TMS 2'de (TMS 23 Borçlanma Maliyetleri standardına atıfta bulunarak) özellikli varlık niteliğinde olan stoklar için geçerli olup bu tür stoklar tamamlanana kadar ilgili borçlanma maliyetleri stoğun maliyetine eklenmekte, daha sonra ortaya çıkan borçlanma maliyetleri ise gider yazılmaktadır.

$\checkmark$ BOBİ FRS Bölüm 6'da, TMS 2'den farklı olarak stok maliyetinin belirlenmesinde normal maliyet yöntemi yanında tam maliyet yönteminden de bahsedilmektedir. Ayrıca normal maliyet yöntemine ilişkin düzenlemeler öne çıkarılmaktadır. Bunun sonucu olarak da üretim maliyeti ve satışların maliyetinin hesaplanmasında farklılıklar getirilmektedir.

\section{Bölüm 7 Tarımsal Faaliyetler}

TMS 41 Tarımsal Faaliyetler standardında yer alan düzenlemeler (Tarımsal ürünlerin ölçümü: gerçeğe uygun değeri üzerinden; canlı varlıkların sunumu, vb.) ile uyumludur. BOBİ FRS Bölüm 7, örnekler ile beraber anlaşılır bir şekilde gruplandırılmıştır. Ayrıca, canlı varlık sınıfının değerleme ölçüsü, TMS 41'de sadece gerçeğe uygun değer iken BOBİ FRS Bölüm 7'de gerçeğe uygun değerin yanında maliyet ile ölçüm alternatifi getirilmektedir.

\section{Bölüm 8 Maden Kaynaklarının Aranması ve Değerlendirilmesi}

TRFS 6 Maden Kaynaklarının Araştırılması ve Değerlendirilmesi standardındaki düzenlemeler (İlk kayıt: maliyet bedeli; arama ve değerlendirme varlıklarının sınıflandırması: maddi veya maddi olmayan duran $v a r l ı, v b$.) ile uyumludur. İki düzenleme arasındaki tek farklılık; sonraki ölçümde BOBİ FRS Bölüm 8'de maliyet bedelinin, TFRS 6'da maliyet bedeli ve yeniden değerleme modelinin yer almasıdır.

\section{Bölüm 9 Finansal Araçlar ve Özkaynaklar}

BOBİ FRS Bölüm 9, Tam Set TMS/TFRS'de yer alan finansal araçlar ile ilgili 4 standart ile uyumlu düzenlemeler (Borçlanma aracı niteliğindeki menkul kıymet yatırımlarının ile banka kredileri ve ihraç edilen menkul kıymetlerin ölçümü: itfa edilmiş maliyeti üzerinden; türev araçlar: gerçeğe uygun değeri üzerinden ölçülür; vb.) olmakla birlikte daha anlaşılır ve sade bir yapıya sahiptir. İki düzenleme arasındaki farklılıklar ise şunlardır:

\section{$\checkmark$ BOBİ FRS Bölüm 9'da finansal araçlar;}

- Ticari ve diğer alacaklar, borçlanma araçları, özkaynak araçlarındaki yatırımlar ve diğer finansal varlıklar olarak sinıflandırılmakta ve

- Tüm ölçüm farkları kar zarara yansıtılmaktadır. TFRS 9'dan farklı olarak finansal varlıklar ile ilgili ölçülen gerçeğe uygun değer farklarının diğer kapsamlı gelire yansıtılma durumu ortadan kalkmıştır.

TFRS 9'a göre yapılan sinıflamada;

- Finansal varlıklar; itfa edilmiş maliyeti ile ölçülen, gerçeğe uygun değer farkı kar veya zararda sınıflandırılarak ölçülen ve gerçeğe uygun değer farkı diğer kapsamlı gelirde sınıflandırılarak ölçülen finansal varlıklar olmak üzere,

- Finansal borçlarda; itfa edilmiş maliyeti ile ölçülen, gerçeğe uygun değer farkı kar veya zararda sınıflandırılarak ölçülen borçlar olmak üzere sınıflandırılmaktadır. 
Finansal varlıklardaki değer düşüklüğü için TFRS 9'da belirtilen beklenen kredi zararı yaklaşımı BOBİ FRS Bölüm 9'da yer almamaktadır. Bunun yerine, BOBİ FRS'de değer düşüklüğüne ilişkin gözlemlenebilir kanıtların bulunması durumunda değer düşüklüğü karşılığı ayrılmaktadır.

$\checkmark$ BOBİ FRS’de; ticari ve diğer alacak ve borçlardan vadesi bir yıldan kısa olanlar itibari değerleri üzerinden, vadesi bir yıldan uzun olanlar ise itfa edilmiş değerden ölçülmektedir. TFRS'de ise vadesine bakılmaksızın tüm alacak ve borçlar itfa edilmiş değerleri üzerinden izlenmektedir.

TFRS'de, hisse senetlerinin tamamı borsada işlem görme ayırımı olmaksızın gerçeğe uygun değeri üzerinden, BOBİ FRS'de ise borsada işlem görmeyen hisse senetleri maliyet bedeli, borsada işlem görenler gerçeğe uygun değer üzerinden izlenmektedir.

\section{Bölüm 10 İştiraklerdeki Yatırımlar}

TMS 28 İştiraklerdeki ve İş Ortaklıklarındaki Yatırımlar standardındaki düzenlemeler (İştirak yatırımının tanımı: önemli etkinin bulunması; konsolide finansal tablolarda iştirak yatırımının ölçümü: özkaynak yöntemi, vb.) ile uyumludur. Sadece, TMS 28'de iştirak yatırımının ölçülmesi hususunda; (münferit finansal tablolarda) maliyet bedeli, özkaynak yöntemi ve gerçeğe uygun değer yer almakta iken BOBİ FRS‘de ise maliyet bedeli ve özkaynak yöntemi yer almaktadır.

\section{Bölüm 11 Müşsterek Girişimlerdeki Yatırımlar}

TFRS 11 Müşterek Anlaşmalar standardındaki düzenlemeler (Müşterek kontrol, konsolide finansal tablolarda müştereken kontrol edilen işletmelerin muhasebeleştirilmesi: özkaynak yöntemi, vb.) ile uyumludur. Sadece, TFRS 11'de müşterek kontrol edilen işletmelerin muhasebeleştirilmesinde (münferit finansal tablolarda); maliyet bedeli, özkaynak yöntemi ve gerçeğe uygun değer yer alırken BOBİ FRS‘de ise maliyet bedeli ve özkaynak yöntemi yer almaktadır.

\section{Bölüm 12 Maddi Duran Varlıklar}

TMS 16 Maddi Duran Varlıklar standardındaki düzenlemeler (İlk ölçüm: maliyet bedeli; sonraki ölçüm: maliyet bedeli ya da yeniden değerlenmiş tutar; amortisman uygulamaları: faydalı ömür, amortismana tabi tutar, amortisman yöntemleri, değer düşüklüğ̈̈, vb.) ile uyumludur. İki düzenleme arasındaki önemli farklılıklar şunlardır:

$\checkmark$ BOBİ FRS Bölüm 12'de bir yıldan kısa vadeli ödeme karşılığında alınan maddi duran varlıklarda vade farkı ayrıştırılmamakta, sadece maddi duran varlığın bir yıldan daha uzun vadeli bir ödeme karşılığında satın alınması durumunda vade farkı tutarı ayrıştırılmakta ve faiz gideri olarak muhasebeleştirilmektedir. TMS 16'da ise tüm vade farkları vade süresine bakılmaksızın ayrıştırılmaktadır.

$\checkmark$ BOBİ FRS Bölüm 12'de maddi duran varlıklara ilişkin borçlanma maliyetleri, oluştukları dönemde kâr veya zarara yansıtılmaktadır. Sadece, inşası normal şartlar altında bir yıldan daha uzun süren maddi duran varlıklar için katlanılan borçlanma maliyetleri kullanıma hazır hale geldiği tarihe kadar maddi duran varlığın maliyetine dâhil edilmektedir. Bu durum TMS 16’da (TMS 23 Borçlanma Maliyetleri standardına atıfta bulunarak) özellikli varlık niteliğinde olan maddi duran varlıklar için geçerli olup bu tür varlıklar tamamlanana kadar ilgili borçlanma maliyetleri varlığın maliyetine eklenmekte, daha sonra ortaya çıkan borçlanma maliyetleri ise gider yazılmaktadır.

\section{Bölüm 13 Yatırım Amaçlı Gayrimenkuller}

TMS 40 Yatırım Amaçlı Gayrimenkuller standardındaki düzenlemeler (İlk kayıt ve ölçüm: maliyet bedeli; sonraki ölçüm: maliyet ya da gerçeğe uygun değer yöntemi, sunum: finansal durum tablosunda yatırım amaçlı gayrimenkuller kalemi olarak, vb.) ile uyumludur. 


\section{Bölüm 14 Maddi Olmayan Duran Varlıklar}

TMS 38 Maddi Olmayan Duran Varlıklar standardında yer alan çoğu düzenleme (ilk kayıt ve ölçüm: maliyet bedeli, araştırma ve geliștirme safhası ayrımı, itfa uygulamaları: faydalı ömür, itfaya tabi tutar, itfa yöntemleri, değer düşüklügü̈, vb.) ile uyumludur. İki düzenleme arasındaki farklılıklar ise şunlardır:

$\checkmark$ Maddi olmayan duran varlıklar kayda alınmadan sonraki dönemlerde BOBİ FRS Bölüm 14 'te sadece maliyet (gerçeğe uygun değer seçeneği yok); TMS 38'de ise maliyet ya da gerçeğe uygun değeri ile ölçülmektedir.

$\checkmark$ BOBİ FRS'de sınırsız faydalı ömre sahip maddi olmayan duran varlıklar, en az 5 en çok 10 yıl olmak üzere itfa edilmekte iken TMS'de sınırsız faydalı ömre sahip ilgili varlıklar itfa edilmemektedir.

$\checkmark$ BOBİ FRS'de şerefiye, ölçülebiliyor ise itfa ömrü boyunca, ölçülemiyor ise 10 y1lda itfa edilmekte ve değer düşüklüğü testine tabi tutulmamaktadır. TMS'de şerefiye, itfa edilmemekte, sadece değer düşüklüğü testine tabi tutulmaktadır.

\section{Bölüm 15 Kiralamalar}

TMS 17 Kiralama İşlemleri standardındaki düzenlemeler (Kiralama işlemlerinin sınıflandırılması, satış ve geri kiralama işlemleri, vb.) ile genel olarak uyumludur. Sadece TMS 17'de "Faaliyet Kiralaması" olarak tanımlanan kiralama çeşidi, BOBİ FRS Bölüm 15’te “Geleneksel Kiralama” olarak adlandırılmaktadır.

\section{Bölüm 16 Devlet Teșvikleri}

TMS 20 Devlet Teşviklerinin Muhasebeleştirilmesi ve Devlet Yardımlarının Açıklaması standardındaki düzenlemeler (Devlet teşviklerinin kapsamı, vb.) ile uyumludur. Düzenlemeler arasındaki tek farklılık; devlet teşvikleri, BOBİ FRS Bölüm 16'da, tahsil edildiklerinde kâr veya zarara yansitılmakta iken TMS 20 'de, teşviğin kâr ya da zarar dışında yer aldığ sermaye yaklaşımı veya teşviğin bir veya daha fazla dönemde kâr ya da zararda yer aldığı gelir yaklaşımından biri ile muhasebeleştirilmektedir.

\section{Bölüm 17 Borçlanma Maliyetleri}

TMS 23 Borçlanma Maliyetleri standardındaki düzenlemeler (Borçlanma maliyetlerinin unsurları: vade, faiz ve kur farkl, vb.) ile uyumludur. Sadece, TMS 23'te kullanılan “özellikli varlık” tanımlaması yerine BOBİ FRS Bölüm 17'de “üretilmesi, inşası ya da oluşturulması normal şartlar altında bir ylldan daha uzun süren varlıklar" ifadesi kullanılmaktadır. Bu tür varlıklar ile ilgili borçlanma maliyetlerine dair BOBİ FRS ve Tam Set TMS/TFRS'lerde farklılaşan noktalara ilgili varlıkların ait olduğu bölümlerde (B6 Stoklar, B12 Maddi Duran Varlıklar, B13 Yatırım Amaçlı Gayrimenkuller ve B14 Maddi Olmayan Duran Varlıklar) yer verilmiştir.

\section{Bölüm 18 Varlıklarda Değer Düşüklüğ̈̈}

TMS 36 Varlıklarda Değer Düşüklüğü standardındaki düzenlemeler (Ölçüm: defter değeri ile geri kazanılabilir tutar farkı; geri kazanılabilir tutar: satış maliyetleri düşülmüş gerçeğe uygun değer ya da kullanım değeri) ile uyumludur. Tek farklılık, şerefiye, TMS 36'da değer düşüklüğü testine tabi tutulmakta iken BOBİ FRS Bölüm 18'de tutulmamaktadır.

\section{Bölüm 19 Karşıllklar, Şarta Bağlı Yükümlülükler ve Şarta Bağlı Varllklar}

TMS 37 Karşılıklar, Koşullu Borçlar ve Koşullu Varlıklar standardındaki düzenlemeler (Karşıllkların muhasebeleştirilme ölçütleri, koşullu borç ve varlıkların gösterimi, vb.) ile genel olarak uyumludur. İki düzenleme arasındaki farklılık arz eden hususlar ise şunlardır:

$\checkmark$ TMS 37'deki Koşullu Borçlar, BOBİ FRS Bölüm 19'da Şarta Bağlı Yükümlülükler; Koşullu Varlıklar ise Şarta Bağlı Varlıklar olarak isimlendirilmiştir.

Karşılık tutarının hesaplanması ile ilgili olarak; BOBİ FRS Bölüm 19'da bugünkü değer ya da beklenen harcama tutarı, TMS 37'de ise bugünkü değer esas alınmaktadır.

$\checkmark$ Kıdem tazminatının hesaplanmasında BOBİ FRS, aktüeryal hesaplamanın yerine cari dönemde ortaya çıkan kıdem tazminatı artışlarını hesaplamakta ve finansal tablolara yansıtılabilmekte iken TMS 37'de aktüeryal hesaplama kullanılmaktadır. 


\section{Bölüm 20 Yabancı Para Çevrim İşlemleri}

TMS 21 Kur Değişiminin Etkileri standardında yer alan düzenlemeler (İlk ölçüm: işlem tarihindeki spot kur; yabancı para cinsinden parasal ve parasal olmayan kalemlerin çevrimi, finansal tabloların çevrimi, $v b$.) ile uyumludur.

\section{Bölüm 21 İş Birleşmeleri}

TFRS 3 İşletme Birleşmeleri standardında yer alan düzenlemeler (Şerefiyenin ortaya çıkması, iş birleşmesinin muhasebeleştirilmesi: satın alma yöntemi, vb.) ile uyumludur. İki düzenleme arasındaki farklılıklar şunlardır:

$\checkmark$ Şerefiye; BOBİ FRS Bölüm 21'de, iş birleşmesinin maliyeti ile edinilen varlık ve yükümlülüklerin defter değeri veya gerçeğe uygun değeri arasındaki fark; TFRS 3’te ise iş birleşmesinin maliyeti ile edinilen varlık ve yükümlülüklerin gerçeğe uygun değeri arasındaki fark olarak tanımlanmaktadır.

$\checkmark$ Şerefiye BOBİ FRS'de, güvenilir bir şekilde tahmin edilebiliyor ise faydalı ömrü boyunca, tahmin edilemiyor ise 10 yılda itfa edilmekte iken TFRS 3'e göre itfa edilmemektedir.

$\checkmark$ TFRS 3’te pazarlıklı satın almadan kaynaklanan kazanç, BOBİ FRS Bölüm 21'de negatif şerefiye olarak isimlendirilmektedir.

\section{Bölüm 22 Konsolide Finansal Tablolar}

TFRS 10 Konsolide Finansal Tablolar standardındaki düzenlemeler (Bağlı ortaklık kıstası: kontrolün bulunması; konsolidasyon işlemleri; kontrol gücü olmayan paylar, vb.) ile genel olarak uyumludur. Düzenlemeler arasındaki önemli farklılıklar ise şunlardır:

$\checkmark$ BOBİ FRS Bölüm 22’ye göre konsolide finansal tablo hazırlama sadece büyük işletmelerde zorunlu olup, orta ölçekli işletmelerde ise isteğe bağlıdır. TFRS 10'a göre de tam seti kullanan tüm işletmelerin konsolide finansal tablo hazırlamaları zorunlu tutulmaktadır.

Bağlı ortaklıkların muhasebeleştirilmesinde (münferit finansal tablolarda); TFRS 10’da, maliyet bedeli, özkaynak yöntemi ve gerçeğe uygun değer, BOBİ FRS Bölüm 22‘de ise maliyet bedeli ve özkaynak yöntemi yer almaktadır.

\section{Bölüm 23 Gelir Üzerinden Alınan Vergiler}

TMS 12 Gelir Vergileri standardında yer alan düzenlemeler (Dönem vergisi, ertelenmiş vergi, vb.) ile uyumludur. En önemli fark, TMS 21'e göre tam seti kullanan tüm işletmelerin finansal tablolarında, ertelenmiş verginin hesaplanması ve sunulması zorunlu iken, BOBİ FRS Bölüm 23’e göre sadece büyük işletmeler için ertelenmiş vergi hesaplaması ve sunumu zorunlu tutulmakta, orta ölçekli işletmelerde ise bu şekilde bir zorunluluk bulunmamaktadır.

\section{Bölüm 24 Ara Dönem Finansal Raporlama}

TMS 34 ile Ara Dönem Finansal Raporlama standardındaki düzenlemeler (Ara dönem finansal raporların içeriği, yer verilmesi gereken açıklamalar, sunulması gereken dönemler, vb.) ile uyumludur. Ancak TMS 34'e göre tam seti kullanan işletmeler ara dönem finansal tablo hazırlamak zorunda iken BOBİ FRS Bölüm 24'e göre işletmelere ara dönem finansal tablo hazırlama yükümlülüğü getirilmemektedir. Bu işletmeler, tabi oldukları mevzuat uyarınca zorunlu ya da isteğe bağlı olarak ara dönem finansal tablo hazırlayacaklardır.

\section{Bölüm 25 Yüksek Enflasyonlu Ekonomilerde Finansal Raporlama}

TMS 29 Yüksek Enflasyonlu Ekonomilerde Finansal Raporlama standardındaki düzenlemeler (Finansal tabloların enflasyona göre düzeltilmesi, vb.) ile uyumludur. Ancak BOBİ FRS Bölüm 25'te ulusal para birimi olarak Türk Lirası belirtilmiş, yüksek enflasyonlu ekonomi kavramı Türkiye’deki enflasyon düzeltmesi kanunu kapsamında açıklanmış ve ağırlıkla kullanılan para birimi Türk Lirası olan işletmelerin genel fiyat endeksi olarak Türkiye İstatistik Kurumunun Türkiye geneli için hesapladığı Yurt İçi Üretici Fiyat Endeksini kullanacağı düzenlenmiştir. TMS 29'da ise bu netlikte bir düzenleme yer almamaktadır. 
Bölüm 26 Dipnotlar $\quad$ BOBİ FRS‘de yer alan ve tüm bölümleri kapsayan dipnotlar, ayrı olarak Bölüm 26’da yer almaktadır. Tam Set TMS/TFRS ‘lerde ise dipnotlar için ayrıca bir standart yer almamakta, ancak her standardın içinde söz konusu standart ile ilgili yapılması gereken dipnotlar açıklamalarına yer verilmektedir.

Ayrıca BOBİ FRS Bölüm 26'da belirtilen işletmeler tarafından açıklanması gereken bilgiler; Tüm İşletmeler Tarafindan Yapılacak Açıklamalar, Yalnızca Büyük Işsletmeler Tarafindan Yapılacak Ilave Açıklamalar ve Konsolide Finansal Tablolarda Yapılacak Açıklamalar şeklinde alt başlıklara ayrilmaktadir.

\section{Bölüm 27 Geçiş Hükümleri}

BOBİ FRS’nin uygulanmasına yönelik olarak bu standardı uygulayacak işletmelerin uygulama tarihinde nasıl bir yol izleyecekleri bir başka ifade ile topyekûn BOBİ FRS'yi nasıl uygulayacakları, Bölüm 27 'de açıklanmaktadır. Tam Set TMS/TFRS'de standartlar ile ilgili olarak yeni bir düzenleme geldiğinde o düzenleme ile ilgili geçiş hükümlerine standardın kendi içinde yer verilmektedir. Ayrıca TFRS'leri ilk kez uygulayacak işletmeler için de TFRS 1 Türkiye Finansal Raporlama Standartlarının İlk Uygulaması standardı ile standarda geçiş yapacaklara ilişkin gerekli geçiş hükümleri konusunda açıklamalar yapılmaktadır.

BOBİ FRS Bölüm 27, TFRS 1 standardındaki düzenlemeler (İlk geçiş, muafiyetler, vb.) ile uyumlu olmakla beraber her iki düzenlemenin de kapsamı doğrultusunda farklılıklar (Açıklamalar, vb.) da mevcuttur.

\section{Ekler}

BOBİ FRS, büyük ve orta ölçekli işletmelerin standarttaki bölümleri uygulamaları sonucunda dönem sonlarında oluşturacakları finansal tabloların örneklerini (Ek 1-8) ve bölümlerde geçen önemli kavramların açıklamalarını ( $E k$ 9) ekler kısmında sunmakta ve uygulayıcılar için önemli bir rehber ortaya koymaktadır.

Tam Set TMS/TFRS içinde uygulayıcılar için böyle bir rehber bulunmamakla birlikte KGK tarafindan 20.05.2013 tarihinde yayımlanan "Finansal Tablo Örnekleri ve Kullanım Rehberi" uygulamas1, işletmelerin bu ihtiyacını karşılamakta ve uygulamada birlik sağlamaktadır.

\subsection{BOBİ FRS \& Tam Set TMS/TFRS: Değerlendirme}

Çalışmanın önceki bölümlerinde yapılan BOBİ FRS ve Tam Set TMS/TFRS karşılaştırması bir bütün olarak değerlendirildiğinde şu önemli noktalar ortaya çıkmaktadır:

$\checkmark$ KGK'nın 2016 yılı bağımsız denetim sözleşmesi imzalayan işletmeler verisine göre (6.250 işletme: \%100) (KGK, BOBİ FRS Tanıtım Toplantısı, 2017):

- BOBİ FRS’yi uygulayacak işletme sayısının (4.700 işletme: \%75,2), öngörülmektedir.

- Tam Set TMS/TFRS uygulayacak işletme sayısından (1.550 işletme: \%24,8) fazla olacağı

Bu sayıların ve oranların yıllar içinde bağımsız denetime tabi olma ve büyük ölçekli işletme sayılma kriterlerine ait tutarlarının değişmesi ile birlikte farklılaşacağı ifade edilebilir.

Tam Set TMS/TFRS'de bulunan 44 düzenlemenin \%70,5’i (31'i) BOBİ FRS 'deki bölümlerde kendine yer bulmuştur. \%29,5’i (13’ü) ise BOBİ FRS'de yer almamıştır.

Tablo 4 ve Tablo 5'teki sayfa sayıları verileri değerlendirildiğinde; BOBİ FRS ile ilgili olan Tam Set TMS/TFRS'deki düzenlemelerin toplam sayfa sayısı 703 iken bu sayfa sayısı BOBİ FRS'deki tüm bölümlere 195 sayfa olarak yansımıştır. Bir başka ifade ile Tam Set TMS/TFRS'de BOBİ FRS ile ilgili olan 31 düzenlemenin sayfa sayısının yaklaşık \%28'i BOBİ FRS'deki 27 bölümü oluşturmaktadır. Bu bilgi, KGK tarafından BOBİ FRS ile ilgili yapıldığı ifade edilen sadeleştirmenin de bir kanıtı olarak görülebilir.

$\checkmark$ BOBİ FRS bölümleri ile Tam Set TMS/TFRS'lerin uyumu değerlendirildiğinde (bkz. Bölüm 2.2'deki bilgiler) Tablo 6 ve Tablo 7'deki görünüm ortaya çıkmaktadır. Tablo 6'da, BOBİ FRS Bölümlerinin Tam Set TMS/TFRS ile uyumluluk düzeyleri ve bölüm sayıları kapsamında ele alınmış olup; Tablo 7'de uyumluluk düzeyine göre iki düzenleme arasında farklılık arz eden konuların neler olduğu belirtilmiştir. 
Tablo 6. BOBİ FRS ve Tam Set TMS/TFRS Uyumluluk Düzeyi

\begin{tabular}{|c|l|c|}
\hline $\begin{array}{c}\text { Uyumluluk } \\
\text { Düzeyi* }\end{array}$ & BOBİ FRS Bölümler (B) & $\begin{array}{c}\text { Bölüm } \\
\text { Sayısı }\end{array}$ \\
\hline Yüksek & B2, B3, B4, B5, B7, B8, B10, B11, B13, B15, B16, B17, B18, B20, B23, B24, B27 & 17 \\
\hline Orta & B1, B6, B9, B12, B14, B19, B21, B22, B25 & 9 \\
\hline Düşük & B26 & 1 \\
\hline
\end{tabular}

"Yüksek: En fazla bir; Orta: En az iki veya daha fazla; Düşük: Birçok konuda farklılık olmasl.

Tablo 6'daki BOBİ FRS Bölüm 26'da yer alan ilkeler, Tam Set TMS/TFRS’deki düzenlemeler ile benzerlik gösterse de ayrı bir bölüm olarak ele alınması ve büyük ve orta boy işletmelere özgü düzenlemeler içermesi nedeniyle uyumluluk düzeyi düşük olarak kategorilendirilmiştir.

Tablo 7. BOBİ FRS ve Tam Set TMS/TFRS Uyumlu

\begin{tabular}{|c|c|}
\hline BOBİ FRS & Farklılık Arz Eden Konular \\
\hline B1 Kavramsal Çerçeve ve Finansal Tablolar & $\begin{array}{l}\text { İhtiyatlılık kavramının eklenmesi, Finansal Durum } \\
\text { Tablosunda Satış Amaçlı Duran Varlıklar kaleminin yer } \\
\text { almaması, Kâr veya Zarar Tablosunun sadeleştirilmesi ve } \\
\text { Diğer Kapsamlı Gelir Tablosunun çıartılması. }\end{array}$ \\
\hline B2 Nakit Akış Tablosu & $\begin{array}{l}\text { İșletme Faaliyetlerinin, Esas Faaliyetler olarak } \\
\text { isimlendirilmesi. }\end{array}$ \\
\hline $\begin{array}{l}\text { B3 Muhasebe Politikaları, Tahminler ve } \\
\text { Yanlışlıklar }\end{array}$ & Genel ilkelerde farklılık arz eden konu yok. \\
\hline B4 Raporlama Döneminden Sonraki Olaylar & Genel ilkelerde farklılık arz eden konu yok. \\
\hline B5 Hasılat & Vade farklarının ayrıştırılması. \\
\hline B6 Stoklar & $\begin{array}{l}\text { Vade farklarının ayrıştırılması, borçlanma maliyetlerinin } \\
\text { muhasebeleştirilmesi, tam maliyet yönteminin eklenmesi. }\end{array}$ \\
\hline B7 Tarımsal Faaliyetler & $\begin{array}{l}\text { Canlı varlıkların değerlemesinin maliyet bedeli ile de } \\
\text { ölçülebilmesi. }\end{array}$ \\
\hline $\begin{array}{l}\text { B8 Maden Kaynaklarının Aranması ve } \\
\text { Değerlendirilmesi }\end{array}$ & Sonraki ölçümde sadece maliyet bedelinin yer alması. \\
\hline B9 Finansal Araçlar ve Özkaynaklar & $\begin{array}{l}\text { Finansal araçların sınıflandırılması, değer düşüklüğünde } \\
\text { beklenen kredi zararı yaklaşımının bulunmaması, ticari ve } \\
\text { diğer alacak ve borçların (sadece vadesi bir yıldan uzun } \\
\text { olanlar) itfası, hisse senetlerinin hangi değer üzerinden } \\
\text { izleneceği. }\end{array}$ \\
\hline B10 İştiraklerdeki Yatırımlar & $\begin{array}{l}\text { İştirak yatırımının ölçülmesinde gerçeğe uygun değer } \\
\text { seçeneğinin yer almaması. }\end{array}$ \\
\hline B11 Müşterek Girişimlerdeki Yatırımlar & $\begin{array}{l}\text { Müşterek girişimlerdeki yatırımın ölçülmesinde gerçeğe } \\
\text { uygun değe seçeneğinin yer almaması. }\end{array}$ \\
\hline B12 Maddi Duran Varlıklar & $\begin{array}{l}\text { Vade farklarının ayrıştırılması, borçlanma maliyetlerinin } \\
\text { muhasebeleştirilmesi. }\end{array}$ \\
\hline B13 Yatırım Amaçlı Gayrimenkuller & Genel ilkelerde farklılık arz eden konu yok. \\
\hline B14 Maddi Olmayan Duran Varlıklar & $\begin{array}{l}\text { Varlığın sonraki dönemlerde sadece maliyet bedeli ile } \\
\text { izlenebilmesi, sınırsız faydalı ömre sahip varlıkların itfası, } \\
\text { şerefiyenin itfası ve değer düşüklüğünün testi. }\end{array}$ \\
\hline B15 Kiralamalar & $\begin{array}{l}\text { Faaliyet Kiralamasının, Geleneksel Kiralama olarak } \\
\text { isimlendirilmesi. }\end{array}$ \\
\hline
\end{tabular}




\begin{tabular}{|c|c|}
\hline B16 Devlet Teşvikleri & Devlet teşviklerinin muhasebeleştirilmesi. \\
\hline B17 Borçlanma Maliyetleri & $\begin{array}{l}\text { Özellikli varlık yerine üretilmesi, inşası ya da oluşturulması } \\
\text { normal şartlar altında bir yıldan daha uzun süren varlıklar } \\
\text { tanımlamasının kullanılması. }\end{array}$ \\
\hline B18 Varlıklarda Değer Düşüklüğü & Şerefiyenin değer düşüklüğü testine tabi tutulmaması. \\
\hline $\begin{array}{l}\text { B19 Karşılıklar, Şarta Bağlı Yükümlülükler ve } \\
\text { Şarta Bağlı Varlıklar }\end{array}$ & $\begin{array}{l}\text { Koşullu yerine Şarta Bağlı ifadesinin kullanılması, karşı1lık } \\
\text { tutarının hesaplanmasında beklenen harcama tutarının } \\
\text { kullanılabilmesi, kıdem tazminatının hesaplanması yöntemi. }\end{array}$ \\
\hline B20 Yabancı Para Çevrim İşlemleri & Genel ilkelerde farklilık arz eden konu yok. \\
\hline B21 İş Birleşmeleri & $\begin{array}{l}\text { Şerefiyenin hesaplanması ve itfası, pazarlıklı satın almadan } \\
\text { kaynaklanan kazancın negatif şerefiye olarak } \\
\text { isimlendirilmesi. }\end{array}$ \\
\hline B22 Konsolide Finansal Tablolar & $\begin{array}{l}\text { Hazırlamak zorunda olan işletme kapsamı, bağlı } \\
\text { ortaklıkların muhasebeleştirilmesinde gerçeğe uygun değer } \\
\text { seçeneğinin yer almaması. }\end{array}$ \\
\hline B23 Gelir Üzerinden Alınan Vergiler & Hazırlamak zorunda olan işletme kapsamı. \\
\hline B24 Ara Dönem Finansal Raporlama & $\begin{array}{l}\text { Hazırlanmasının bağlı bulunan mevzuata göre zorunlu ya da } \\
\text { ihtiyari olması. }\end{array}$ \\
\hline $\begin{array}{l}\text { B25 Yüksek Enflasyonlu Ekonomilerde Finansal } \\
\text { Raporlama }\end{array}$ & $\begin{array}{l}\text { Ulusal para birimi olarak, Türk Lirasının; genel fiyat endeksi } \\
\text { olarak da Yİ-ÜFE'nin belirtilmesi. }\end{array}$ \\
\hline B26 Dipnotlar & Ayrı bir bölüm olarak yer alması. \\
\hline B27 Geçiş Hükümleri & Açıklanacak hususların içeriği. \\
\hline
\end{tabular}

Sonuç olarak BOBİ FRS' yer alan 27 bölümden 17 tanesi (\%63'ü), Tam Set TMS/TFRS'de ilgili olduğu standartlardaki ilkeler ile yüksek; 9 tanesi (\%33’ü) orta ve 1 tanesi de (\%4’ü) düşük düzeyde uyumlu olarak tespit edilmiştir.

$\checkmark$ BOBİ FRS ve Tam Set TMS/TFRS'de yer alan bir takım özellikli düzenlemeleri bazı işletmeler için zorunlu tutulurken bazı işletmeler için ise kapsam dışı bırakılmıştır. İki düzenleme bir bütün olarak değerlendirildiğinde Tablo 8'de yer alan durum ortaya çıkmaktadır.

Tablo 8. BOBİ FRS ve Tam Set TMS/TFRS Kapsamındaki

Özellikli Düzenlemeleri Uygulayacak Olan İşletmeler

\begin{tabular}{|c|c|c|c|c|}
\hline & & \multicolumn{3}{|c|}{ İŞLETME } \\
\hline & & KAYİK & Büyük Ölçekli & Orta Ölçekli \\
\hline \multirow{2}{*}{ 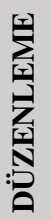 } & $\begin{array}{l}\text { Ertelenmiş Vergi } \\
\text { Hesaplaması }\end{array}$ & $\checkmark$ & $\checkmark$ & - \\
\hline & $\begin{array}{l}\text { Konsolide Finansal Tablo } \\
\text { Hazırlama }\end{array}$ & $\checkmark$ & $\checkmark$ & - \\
\hline
\end{tabular}

BOBİ FRS kapsamında Tablo 8'de görülen düzenlemeleri, orta ölçekli işletmeler uygulamak zorunda değildir. Ancak işletmeler bu düzenlemeleri ihtiyari olarak uygulama seçeneğine sahiptirler. Bununla birlikte, bu işletmelerin isteğe bağlı olarak konsolide finansal tablolarını hazırlamaları durumunda, ertelenmiş vergi tutarlarını sunmaları konsolide finansal tablolarında zorunlu; ancak münferit finansal tablolarinda ihtiyaridir.

Tablo 8'de belirtilen hususlar dişında büyük ölçekli işletmeler, BOBİ FRS Bölüm 26 Dipnotlar paragraf 26.8'e göre orta ölçekli işletmelerden farklı olarak aşağıda belirtilen konularda da açıklama yapmak durumundadır: 
- Ürünlerin satışl ile hizmetlerin sağlanmasının organize ediliş biçimleri dikkate alınarak, önemli ölçüde birbirlerinden farklı faaliyet kategorileri ve coğrafi piyasalar itibarılyla ayrıştırılmış net satış hasilatt.

- Illişkili tarafların tamamıyla yapılan işlemler, bu işlemlerin tutarı, ilişkili taraf iliş̧kisinin niteliği ve işletmenin finansal durumunun anlaşılmast için işlemlerle ilgili gerekli olan diğer bilgiler.

\section{SONUÇ}

Türkiye'de vergi odaklı muhasebe düzenlemeleri, muhasebe ve finansal raporlama standartlarının gündeme gelmesi ile birlikte daha fazla sorgulanır hale gelmiştir. Finansal tabloların gerçeğe uygun ve şeffaf hazırlanması için bağımsız denetime tabi olup TMS/TFRS uygulamayan işletmeler için oluşturulan BOBİ FRS'ler de bu durumu daha da pekiştirmiş̧tir. Ancak BOBİ FRS ile yapılan düzenlemeler doğrultusunda, işletmelerin ticari kar ile mali kar farklılıklarının belki de vergi kanunlarına yapılacak ilave düzenlemeler ile daha aza indirgenmesi sağlanabilecektir ki bu konuda bir çalışma olduğu da bilinmektedir.

Gelişmiş ülkelerdeki finansal tablo ve muhasebe uygulamaları, salt vergi düzenlemeleri için değil ticari karın doğru ve dürüst bir şekilde gösterimi amacı ile yapılmaktadır. Türkiye'deki durum ise TMS/TFRS dışındaki düzenlemeler açısından vergi odaklıdır. Türkiye; muhasebe, raporlama ve denetim alanında dünyada yaşanan gelişmelere hızla uyum sağlayabilme yeteneğine sahip bir durumdadır. Kuşkusuz son yıllarda yapılan gerçeğe uygun ve bilgi odaklı düzenlemelere uyum sağlanması ile beraber Türkiye’deki işletmeler, dünya ticaretinde daha fazla pay alabilecek ve önemli bir rol üstlenecektir.

Türkiye'nin 1992 yılından itibaren Tekdüzen Hesap Planı ve MSUGT ile başlayan, daha sonra TMS/TFRS uyumlaştırmaları ile devam eden muhasebe ve raporlama alanındaki önemli adımları bugün KGK tarafindan düzenlenen BOBİ FRS'ler ile büyük ilerleme kazanmıştır. Bununla birlikte küçük ölçekli işletmeler için de Tam Set TMS/TFRS ve BOBİ FRS ile uyumlu bir setin hazırlanması ya da mevcut düzenlemelerin uyumlaştırılması ve vergi odaklı mevcut düzenlemelerin de gerçeğe uygun ve şeffaf sunum odaklı hale getirilmesi ile bu alandaki ilerleme daha da hızlanacaktır. İşletmelerin de, Türkiye'nin bu alandaki gelişimine sosyal sorumluluk içerisinde ve vergi etiğini esas alarak katkı vereceğine, bu çerçevede BOBİ FRS'nin ülke ekonomisine değer katacağına inanmaktayız. 


\section{KAYNAKÇA}

GÖKÇEN, Gürbüz, ATAMAN, Başak ve ÇAKICI, Cemal. (2016). Türkiye Finansal Raporlama Standartları Uygulamaları, 2. Baskı, İstanbul: Beta Yayınları.

KGK. (2017). Basın Duyurusu: "Büyük ve Orta Boy Işsletmeler Iç̧in Finansal Raporlama Standardı Yayımlanmıştır”. www.kgk.gov.tr (31.07.2017).

KGK. (2017). BOBİ FRS Tanitım Toplantısı. İstanbul (14.09.2017).

KGK. (2017). TMS/TFRS 2017 Seti. www.kgk.gov.tr (7.10.2017).

RESMI GAZETE, Büyük ve Orta Boy Isşletmeler İçin Finansal Raporlama Standardı Hakkında Tebliğ (Sira No: 56). Resmi Gazete Sayısı: 30138 Mükerrer (29.07.2017). 